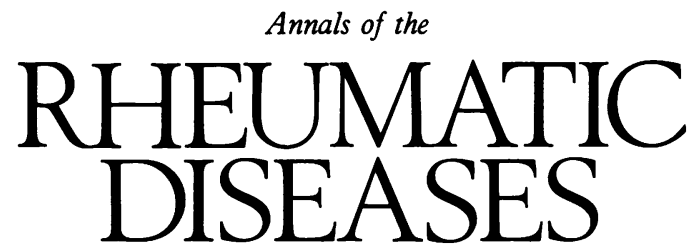

Leader

\title{
Skeletal palaeopathology and the rheumatic diseases: Where are we now?
}

Many rheumatologists have an interest in the history of the rheumatic diseases. Sources of historical data include medical manuscripts, non-medical literature, art, and archaeological specimens such as mummies and skeletons. Skeletal material is more commonly available than mummies and should provide valuable data on rheumatic diseases which leave imprints on bones. Over the last decade there have been an increasing number of publications on arthritis in skeletons; this article briefly reviews these reports and their contribution to rheumatology.

\section{Historical perspective on skeletal palaeopathology}

From the earliest days of organised archaeology in the 19th century the remains of the people have been recovered alongside their artefacts and buildings. The most spectacular series of human remains are the mummies, and during the exploration of Egyptian sites many thousands of both mummies and skeletons were recovered. One of the first recorded scientific examinations of a mummy was that of Granville in the early 1820 s, $^{1}$ but it was Marc Armand Ruffer, working in the early part of this century, who opened up this field of study and introduced the term 'palaeopathology'.'

Most human remains recovered are skeletons with no remaining soft tissue, and this is the material on which most of the work on palaeopathology has been done. Interest in the evidence of disease in bones arose in the 18th century during the examination of Pleistocene (ice age) cave mammal deposits, and was soon expanded by anthropologists to include fossil man. Ruffer, ${ }^{3}$ Moodie, ${ }^{4}$ and Hrdlicka, ${ }^{5}$ among others, wrote the first substantial papers on human skeletal palaeopathology. The discipline expanded after the second world war with the work in this country of Wells, ${ }^{6}$ Brothwell and Sandison. ${ }^{7}$ More recently, archaeology has expanded, and more material has become available. In addition, an increasing number of medically qualified people have taken an interest in skeletal palaeopathology. It is still a minority interest, however, and very few specialists such as rheumatologists or radiologists have helped the archaeologists and anthropologists in their attempts to diagnose and classify human disease from skeletal remains.

Can rheumatic diseases be diagnosed from skeletons? Joint disorders are the commonest recorded abnormality in all published series of skeletal material. It is often difficult to make a 'diagnosis', however.
Most of the major rheumatic diseases affect subchondral and periarticular bone, leaving an imprint that is often characteristic when viewed by radiologists. Modern diagnosis is dependent on the pattern of changes both within and between joints, however, and on a constellation of other clinical, serological, and radiological features unavailable to the skeletal palaeopathologist. Ideally, the whole skeleton is required to help to establish the distribution of the disorder, but arachaeological remains are often fragmented or not fully recovered during excavation. There have been several recent contributions to the problem of disease recognition from skeletons. Rogers and Waldron have outlined a system of classification of most of the common rheumatic diseases for use by anthropologists and others, ${ }^{8}$ and a recent symposium addressed the specific question of the erosive arthropathies. ${ }^{9}$ Another recent publication emphasised the lack of sensitivity of radiographs compared with the visual assessment of bony changes. ${ }^{10}$ Twenty four knees were examined by a palaeopathologist, and the bone radiographs were independently assessed by a radiologist; the palaeopathologist recorded obvious abnormalities in 16 cases, whereas the radiologist only saw changes in two. This emphasises that it is inappropriate to relate studies of prevalence of disease recorded from skeletons to modern epidemiological surveys that rely on other data such as radiology.

The published reports include many cases that show clear evidence of osteoarthritis, gout, ankylosing spondylitis, diffuse idiopathic skeletal hyperostosis (DISH), and septic arthritis. ${ }^{11-15}$ In addition, cases mimicking other seronegative erosive arthropathies-for example, psoriatic or reactive arthritis, have been described. Diagnosis of rheumatoid arthritis (RA) from ancient skeletons remains controversial, however. ${ }^{16} \mathrm{~A}$ few possible cases have been described, ${ }^{17}$ including recent reports of an erosive arthropathy in an early native population in the United States. ${ }^{18}$ Skeletons often have evidence of cortical defects on or around the joint surface, especially in the wrists and shoulders, but it is not clear what these represent. They vary in size, may be invisible on radiographs, and do not usually tally well with our current experience of the distribution and pattern of changes in RA. Some people have interpreted skeletons with many of these lesions as having RA, ${ }^{19}$ others dispute this conclusion. ${ }^{20}$ In addition to these lesions, other skeletons have unequivocal evidence of joint erosion; however, diagnosis remains difficult, the changes are usually asymmetrical, and bony growth around the lesions is often extensive, suggesting the possibility of a 
seronegative spondarthritis. ${ }^{21}$ We remain to be convinced by any of the published cases.

Two dimensional epidemiology

The cause of many rheumatic diseases remains unknown and, as outlined in a recent leader in this journal, epidemiology is a powerful weapon to aid our understanding of their cause. ${ }^{22}$ It has been suggested that the addition of a time dimension to the current geographical and risk factor approaches to current epidemiological studies may be helpful $^{23}$; the antiquity of RA has been of special interest. ${ }^{24}$ If $\mathrm{RA}$ is triggered by an infection or other environmental agent then its prevalence in different countries and in different historical periods might provide vital clues as to the nature of this aetiological agent. The descriptions of possible RA quoted above have led to speculations that it is either a recent disease, a 'New World' disease akin to syphilis, or even of viral origin from outer space $!^{25}$

There are many problems with this approach, other than the absurdity of data-free speculation. ${ }^{26}$ First, the material obtained is sporadic and selected. Secondly, the lack of information on the age and circumstances of any given skeleton is a severe limitation to the interpretation of disease prevalence. Thirdly, it is difficult to prove the negative, in other words, not finding RA may be due to a lack of appropriate specimens rather than absence of the disease; it has been estimated that at least 1000 whole adult skeletons would have to be examined before one would expect to find one definite case of RA. ${ }^{27}$ Finally, there is the persisting problem of diagnosis and the lack of correlation between visual and $x$ ray findings mentioned above.

Nevertheless, interesting trends and findings have emerged on the patterns of rheumatic diseases seen in ancient skeletons. DISH, for example, is easily recognised, and seems to have a prevalence that is similar to that found today. ${ }^{28}$ Similarly, evidence on the prevalence and patterns of osteoarthritis is emerging which suggests that there may be changes in the expression of the condition with time, if not of its overall prevalence. ${ }^{1429}$ As classification criteria improve and more whole skeletons are carefully studied it may be possible to make more definitive statements about the history of certain forms of arthritis.

\section{Understanding disease processes}

The most exciting area of recent development in skeletal palaeopathology is the use of bones to ask specific questions about disease pathogenesis. Skeletons provide a unique, if limited, source of information. It is possible to examine the whole three dimensional bony structure of a joint, as well as the whole skeleton. In addition, bony changes can be examined by a variety of special techniques, such as scanning electron microscopy ${ }^{30}$ and slab radiography, and the bone crystals can be extracted and examined. Recent reports indicate that human and bacterial proteins, including DNA, can also be extracted from ancient bones and probed for the presence of a specific epitope. ${ }^{31}$

These studies might help us to understand the different mechanisms of bone formation and resorption in rheumatic disease, and allow us to correlate them with visual and radiographic findings. In addition, susceptibility epitopes on DNA could be sought and related to the skeletal evidence of a given disease in antiquity. This work is in its infancy, and it will be interesting to see what emerges.
Conclusions

Until recently, the examination of ancient skeletons was only used to attempt a rough 'diagnosis' or infer some aspect of the lifestyle of its owner. Although skeletal palaeopathology remains a minority interest, of limited value in the advancement of rheumatology, it is now clear that serious questions can be considered by this discipline, and that the application of scientific rigour to the field may pay dividends in the future. ${ }^{32}$

JULIET ROGERS PAUL DIEPPE Rheumatology Unit Bristol Royal Infirmary Bristol BS2 8HW

1 Dawson W R. Forword. In: Brothwell D R, Sandison A T, eds. Diseases in antiquity. Springfield, Illinois: Thomas, 1967: vii-x.

Ruffer M A. Studies in palaeopathology in Egypt. fournal of Pathology and Bacteriology 1913; 18: 149-62.

3 Ruffer M A, Rieth A. On osseous lesions in ancient Egyptians. Foumal of Pathology and Bacteriology 1912; 22: 152-96.

4 Moodie R L. The antiquity of disease. Chicago: University of Chicago, 1923. (Science series).

5 Hrdlicka A. Special notes on some of the pathological conditions shown by the skeletal material of the ancient Peruvians. Smithsonian miscellaneous collections 1914; 61: 57-69.

6 Wells C. Bones, bodies and disease. Hudson: Thames, 1964

7 Brothwell D R, Sandison A T, eds. Diseases in antiquity. Springfield, Illinois: Thomas, 1967.

8 Rogers J M, Waldron T, Dieppe P, Watt I. Arthropathies in palaeopathology: the basis of classification according to most probable cause. Fournal of the basis of classification according to

9 Rogers J M, Dieppe P, eds. Introduction. The antiquity of erosive arthropathies. London: Arthritis and Rheumatism Council, 1989: 7-9. (Conference proceedings No 5 .)

10 Rogers J, Watt I, Dieppe P. Comparison of visual and radiographic detection of bony changes at the knee joint. Br Med F 1990; 300: 367-8.

11 Steinboch R T. Palaeopathological diagnosis and interpretation. Thomas Springfield, Illinois: Thomas, 1976.

12 Wells C. A palaeopathological rarity in a skeleton of Roman date. Med His 1973; 17: 399-420.

13 Kramar C. A case of ankylosing spondylitis in mediaeval Geneva. Ossa 1981; 8: $115-29$.

14 Rogers J, Watt I, Dieppe P. Arthritis in Saxon and mediaeval skeletons. $\mathrm{Br}$ Med F 1981; 283: 1668-9.

15 Ortner D J, Putschar W G J. Identification of pathological conditions in human skeletal remains. Boston: Smithsonian Institution Press, 1981 .

16 Rogers J, Dieppe P. The Alabama findings and the New World pathogen theory in antiquity of erosive arthritis. In: Rogers $J$, Dieppe $\mathrm{P}$, eds. The antiquity of erosive arthropathies. London: Arthritis and Rheumatism Council, 1989. (Conference proceedings No 5.)

17 Thould A K, Thould B T. Arthritis in Roman Britain. Br Med f 1983; 287: 1909-11.

18 Rothschild B M, Turner K R, De Luca M A. Symmetrical erosive peripheral polyarthritis in the late archaic period of Alabama. Science 1988; 241: 1488-501.

19 Woods R J, Rothschild B M. Population analysis of symmetrical erosive arthritis in Ohio Woodland Indians (1200 years ago). I R heumatol 1988; 15: arthritis

20 Rogers J. Advisors note in current medical literature. Rheumatology 1989; 8: 141-2.

21 Leden I, Peisson E, Peisson O. Aspects of the history of rheumatoid arthritis in the light of recent osteoarchaeological finds. Scand $\mathcal{Y}$ Rheumatol 1988; 17:

22 Thould A K. Arthritis and epidemiology in Europe. Ann Rheum Dis 1990; 49: $139-40$.

23 Dieppe P A, Rogers J. Two dimensional epidemiology. Br f Rheumatol 1985; 24: 310-2.

24 Short C L. The antiquity of rheumatoid arthritis. Arthritis Rheum 1974; 17: 193-205.

25 Hoyle F. From virus to cosmology. $\mathcal{F}$ Soc Med 1983; 76: 99-111.

26 Wood P H N. Is rheumatoid arthritis a recent disease? In: Dumonde D C, ed. Infection and immunology in the rheumatic diseases. Oxford: Blackwell, 1976: 619-22.

27 Kirwan J. The antiquity of erosive arthropathies: the way forward. In: Rogers J, Dieppe P, eds. Antiquity of erosive arthropathies. London: Arthritis and , Dieppe P, eds. Antiquity of erosive arthropathies. London: Arthritis

28 Rogers J, Watt I, Dieppe P. Palaeopathology of spinal osteophytosis, vertebral ankylosis, ankylosing spondylitis, and vertebral hyperostosis. vertebral ankylosis, ankylosing Spon
Ann Rheum Dis 1985; 44: 113-20.

29 Van Saase J C L M, van Romunde L K J, Cats A, Vandenbroucke J P, Valkenburg $\mathrm{H}$ A. Epidemiology of osteoarthritis: Zoetermeer survey. Valkenburg H A. Epidemiology of osteoarthritis: Zoetermeer survey. Comparison of radiological osteoarthritis in a Dutch popul

30 Leisen J C, Duncan H, Riddle J M. Scanning electron microscopy of the rheumatoid erosion in macerated bone specimens. In: Rogers J, Dieppe P, eds. Antiquity of erosive arthropathies. London: Arthritis and Rheumatism Council, 1989: 21-4. (Conference proceedings No 5.)

1 Hagelberg E, Sykes B. Ancient bone DNA amplified. Nature 1989; 342: 485.

32 Shulman L E. Rheumatological advances from critical scientific and artistic retrospection. In: Appelboom T, ed. Art, history and antiquity of rheumatic diseases. Brussels: Elsevier, 1987: 8-10. 